\title{
Faaliyet Tabanlı Maliyetleme Tekniğinde Maliyet Sürücülerinin Analitik Hiyerarşi Prosesi ile Belirlenmesi: Bir Uygulama \\ (Determining Cost Drivers in Activity Based Costing with Analytical Hierarchy Process: A Case Study)
}

\section{Mehmet ÖZÇALICI iD a Ahmet KAYA iD b}

a Kilis 7 Aralık Üniversitesi İktisadi ve İdari Bilimler Fakültesi, Uluslararası Ticaret ve Lojistik Bölümü, Kilis, Türkiye. mozcalici@gmail.com

b Akdeniz Üniversitesi Uygulamalı Bilimler Fakültesi, Bankacılık ve Finans Bölümü, Antalya, Türkiye. ahmetkaya@akdeniz.edu.tr

\begin{tabular}{|c|c|}
\hline MAKALE BİLGİSİ & ÖZET \\
\hline Anahtar Kelimeler: & Amaç - Bu çalışmanın amacı, birim mamul maliyetinin daha doğru hesaplanmasını sağlayabilecek \\
\hline Faaliyet Tabanlı Maliyetleme & $\begin{array}{l}\text { Analitik Hiyerarşi Prosesi temelli Faaliyet Tabanlı Maliyetleme sistemini kurmak ve faaliyet sürü- } \\
\text { cülerinde toplanan giderlerin faaliyetlere ve mamullere doğru bir şekilde dağıtılmasını sağlamaktır. }\end{array}$ \\
\hline Maliyet Dağıtımı & $\begin{array}{l}\text { Yöntem - Bu çalışmada; maliyetlerin dağıtılmasında kullanılacak sürücüler, Analitik Hiyerarşi Pro- } \\
\text { sesi (AHP) yardımıyla belirlenmiştir. Bu amaçla; beş farklı uzman, dağıtım anahtarlarını belirlemek } \\
\text { için değerlendirmelerde bulunmuşlardır. Değerlendirmeler arasındaki uzlaşı, geometrik ortalama } \\
\text { yardımıyla sağlanmıştır. }\end{array}$ \\
\hline 2019 & Bulgular - Elde edilen sonuçlar işletmenin hâlihazırda uyguladı̆̆g geleneksel maliyet sistemi sonuç- \\
\hline Revizyon Tarihi 25 Kasım 2019 & $\begin{array}{l}\text { ları ile karşılaştırılmıştır. FTM-AHP tekniği ile hesaplanan birim maliyetler ile işletmenin kullandığ } 1 \\
\text { geleneksel yönteme göre hesaplanan birim maliyetler arasında farklılıklar olduğu tespit edilmiştir. }\end{array}$ \\
\hline III 10 Aranik 2019 & $\begin{array}{l}\text { Tartışma - Çalışma sonucunda elde edilen bulgular, mamullere ilişkin birim maliyetleri doğru bir } \\
\text { biçimde hesaplamak isteyen işletmeler için büyük önem arz etmekle birlikte geleneksel yöntemler }\end{array}$ \\
\hline $\begin{array}{l}\text { Makale Kategorisi: } \\
\text { Araştırma Makalesi }\end{array}$ & $\begin{array}{l}\text { kullanılarak hesaplanan birim mamul maliyetlerin yetersizliğini de ortaya koymaktadır. Birim ma- } \\
\text { mul maliyetlerini belirlemek için bu çalışmada kullanılan FTM-AHP entegre yönteminin işletmeler } \\
\text { tarafından kolaylıkla uygulanabileceği ve işletmelere rekabet avantajı sağlamada etkili olabileceği } \\
\text { belirlenmiştir. }\end{array}$ \\
\hline
\end{tabular}

\begin{tabular}{ll}
\hline ARTICLE INFO & ABSTRACT \\
\hline $\begin{array}{l}\text { Keywords: } \\
\text { Activity Based Costing } \\
\text { Analytical Hierarchy Process } \\
\text { Cost Allocation }\end{array}$ & $\begin{array}{l}\text { Purpose - The aim of this study is to establish the Activity Based Costing system based on the Ana- } \\
\text { lytical Hierarchy Process, which could provide a more accurate calculation of the unit product cost, } \\
\text { and to ensure that the expenses collected in the activity drivers are distributed to the activities and } \\
\text { the products correctly. } \\
\text { Design/methodology/approach - In this study, the drivers to be used in the distribution of costs } \\
\text { were determined with the help of Analytic Hierarchy Process (AHP). For this purpose, five different } \\
\text { experts made evaluations to determine the allocation keys. The agreement between the evaluations }\end{array}$ \\
$\begin{array}{l}\text { Received 10 September 2019 } \\
\text { Revised 25 November 2019 achieved with the help of the geometric mean. } \\
\text { Accepted 10 December 2019 }\end{array}$ & $\begin{array}{l}\text { Findings - The results obtained were compared with the results of the traditional cost system that } \\
\text { the enterprise has already implemented. It has been determined that there are differences between } \\
\text { the unit costs calculated with ABC-AHP technique and the traditional method used by the enter- } \\
\text { prise. } \\
\text { Discussion - The findings obtained from the study are of great importance for the enterprises which } \\
\text { want to calculate the unit costs related to the products correctly, but they also show the insufficiency } \\
\text { of the unit manufactured costs calculated using traditional methods. It has been determined that the } \\
\text { ABC-AHP integrated method used in this study to determine unit product costs can be easily used } \\
\text { besearch Article }\end{array}$ \\
$\begin{array}{l}\text { by enterprises and can give competitive advantage to enterprises. }\end{array}$
\end{tabular}




\section{Gírìş}

Müşterilerin satın aldıkları ürün için fazla para ödemek istemediği istisna durumlar dışında ürünün satış fiyatı genellikle piyasa tarafından belirlenmektedir. Bu durum, elde edilecek kârın ürün maliyetlerine bağlı olduğunu göstermektedir. Dolayısıyla ürünün maliyetinin yönetimi ve maliyetlerin sistematik olarak kontrolü, işletmelerin rekabetçi bir ortamda faaliyetlerini sürdürebilmeleri açısından önem arz etmektedir. Bununla birlikte üretim işletmelerinin karşılaştıkları en önemli problemlerden biri, ürettikleri ürünlerin birim maliyetini hesaplamak ve değerlendirmektir (Ríos-Manríquez, Colomina ve Pastor, 2014, s. 220). Söz konusu bu üretim işletmelerinden birisi sosyal kaynaşma, yerel istihdam ve yenilik açısından önem arz eden ve birçok ülkenin ekonomisinde önemli bir rol oynayan Küçük ve Orta Ölçekli İşletmeler (KOBİ'ler)'dir. Gelişen dünyada, ekonomik faaliyetlerin yaklaşık yüzde 99'unun kökeninde KOBI'ler yer almaktadır. Benzer durum KOBI'lerin tüm işletmelerin yüzde 90'ından fazlasını oluşturduğu gelişmekte olan ülkelerde de görülmektedir (Auzzir, Haigh ve Amaratunga, 2018, s.1131). KOBI'ler rekabet edebilmek için bir takım zorlukla karşılaşmaktadırlar. KOBİ'ler bu zorluklar karşısında maliyetlerini doğru hesaplayarak maliyet sistemini kontrol edecek stratejiler geliştirmek zorundadırlar (Ríos-Manríquez v.d., 2014, s.220). Yıllar boyunca birçok maliyet belirleme yöntemi geliştirilmiştir. Bu yöntemlerden birisi birçok akademisyen ve uygulayıcı tarafından yirminci yüzyılda yönetim muhasebesindeki en önemli yeniliklerden biri olarak kabul edilen faaliyet tabanlı maliyetleme yöntemidir (Ganorkar, Lakhe ve Agrawal, 2018, s.87).

Faaliyet Tabanlı Maliyetleme yöntemi, şirketlerin rekabetçi maliyetleri elde etme gereksinimleri ve bunun geleneksel maliyet yöntemleri ile yapılamaması ve geleneksel yöntemdeki eksikliklerden dolayı Kaplan ve Cooper tarafından geliştirilmiştir (Kaplan ve Cooper, 1988, s.1991). Kaplan ve Cooper karar verme için geleneksel maliyet yöntemi hakkında kullanıcıların düşünme biçimini değiştirmiştir (Ríos-Manríquez v.d., 2014, s.221). Yapılan çalışmalarda, bu yöntemin maliyetleri kontrol etmek için sağladığı avantajların kanıtları sunulmuştur (Baykasoğlu ve Kaplanoğlu, 2008; Lin, 2012; Kabinlapat ve Sutthachai, 2017). Bu avantajlarına rağmen FTM'yi uygulayabilmek için kaynak ve faaliyet sürücülerinin belirlenmesi gerekmektedir. Birçok küçük ve orta büyüklükteki işletme, bu sürücüleri etkili bir şekilde belirleyecek altyapıya sahip olmadıkları içim bir takım engeller ile karşılaşmaktadır.

Genel üretim giderlerinin ürünlere yüklenmesine ilişkin ortaya çıkan problemlerin temel nedeni; imalat teknolojilerindeki hızlı gelişmelerin ve değişimlerin, üretim yapılarının değişimini de beraberinde getirmesidir. Çünkü üretim yapılarındaki bu değişimler, ürün maliyetlerinin yapısını büyük ölçüde değiştirmektedir. Dolayısıyla üretimde makine kullanımı artmakta iken çalışan sayısı azaldığından dolayı direkt işçilik giderlerinde önemli azalmalar olmaktadır. Bu noktada; söz konusu giderlerin ürünlere yüklenmesinde kullanılan dağıtım yönteminin ve anahtarının belirlenmesi, makine odaklı üretimin yaygınlaştığı bir ortamda çok daha önemli hale gelmektedir (Alkan, 2005, s.39-40). Bununla birlikte geleneksel olarak genel giderlerin dağıtımı, işgücü maliyetinin önemi nedeniyle, işçilik veya makine süresine dayalı olmaktaydı ve bu durum hala birçok firma tarafından uygulanmaktadır. Ancak günümüz üretim işletmelerinde işgücü emeğinin geri planda kalması, söz konusu genel gider dağıtım yöntemlerinin yetersiz hale gelmesine neden olmaktadır (Partovi, 1991, s.151).

Firmalar, genel gider dağıtımına ilişkin farklı yöntemler kullanmaktadır. Söz konusu dağıtıma ilişkin en yaygın kullanılan yöntem iki aşamalı süreçtir. İki aşamalı süreç yönteme göre; genel giderler öncelikle üretim ve tedarik giderleri gibi bir veya daha fazla genel kategoride toplanmaktadır. Daha sonra, bu maliyetler; işçilik saatleri, makine saatleri ve direkt malzeme maliyetleri kullanılarak ürünler arasında paylaştırılmaktadır. İlk aşama, birçok firma tarafından gayet iyi bir şekilde yerine getirilirken ikinci aşamadaki maliyetleri paylaştırma konusunda çoğu muhasebe sistemi eksik kalmaktadır (Partovi, 1991: s.152). Bununla birlikte ürüne ilişkin maliyetleri doğru bir şekilde belirlemek, firmanın karlılığı ve kaynaklarının etkin ve verimli kullanımı açısından önem arz etmektedir.

Partovi (1991) çalışmasında dağıtım anahtarına ilişkin gerekli bilgilerin mevcut bulunmadığı durumlarda, sürücülerin AHP ile belirlenmesini önermektedir (FTM-AHP) ve çalışmasında bir uzmanın ikili karşılaştırmaları yardımıyla örnek bir uygulamaya yer vermiştir. Bu çalışmada ise faaliyet sürücüleri, sadece bir uzman görüşü yerine, bir grup uzmanın değerlendirmelerini dikkate almak suretiyle belirlenmiştir. Bu amaçla; Gaziantep Organize Sanayi Bölgesi'nde faaliyetlerini sürdüren bir un üretim işletmesinin maliyet sistemi incelenmiştir. İşletme hâlihazırda geleneksel maliyet sistemini kullanmaktadır. Kullandıkları sistemde, toplam maliyet 


\section{M. Özçalıcı - A. Kaya 11/4 (2019) 3035-3050}

ürünlere üretim miktarları ile doğru orantılı olarak dağıtılmaktadır. Ancak bu durumda, eğer bir ürünün maliyeti, gerçekte kullandığı kaynaktan daha düşük (yüksek) olarak hesaplanmışsa, mutlaka, bir başka ürünün maliyeti de yüksek (düşük) hesaplanmış olacaktır (Horngren v.d. 2015, s.198). Bu durum, işletmenin birim maliyetlerini yanlış hesaplamasına ve zarara uğramasına neden olacaktır. Bu şekilde olumsuz bir durumla karşılaşmamak ve rekabet üstünlüğü sağlamak için işletmeler, etkili bir birim maliyet hesaplama tekniğine ihtiyaç duymaktadırlar.

Çalışma beş bölümden oluşmaktadır. Bu giriş bölümünden sonra birinci bölümde literatürde yapılmış çalışmalara değinilmektedir. İkinci bölümde Faaliyet Tabanlı Maliyetleme ve Analitik Hiyerarşi Prosesi teknikleri açıklanmaktadır. Üçüncü bölümde önerilen model ve önerilen modelin uygulandığı işletme hakkında bilgi verilmektedir. Dördüncü bölümde uygulama sonuçları yer almaktadır. Son olarak sonuç bölümün

\section{LITERATÜR TARAMASI}

Literatür araştırmasında, Faaliyet Tabanlı Maliyetleme yönteminin birçok alanda uygulandığı belirlenmiştir. Bu çalışmaları aşağıdaki gibi özetlemek mümkündür. Baykasoğlu ve Kaplanoğlu (2008) FTM tekniğini, Türkiye'de faaliyet gösteren bir karayolu lojistik firmasına uygulamışlardır. FTM'nin etkinliğini arttırmak için FTM'yi iş süreci modelleme ve analitik hiyerarşi yaklaşımı ile birleştiren bir bütünleşik yaklaşım önermişlerdir. Önerilen yaklaşımın, firmanın maliyetlendirme hizmetlerinde, mevcut geleneksel maliyetleme sistemine kıyasla oldukça etkili olduğunu sonucuna ulaşılmıştır.

Esmeray ve Güngör Tanç (2009), Kayseri'de faaliyet gösteren bir sanayi işletmesi üzerinde yaptıkları çalışma ile çevresel maliyetlerin mamullere yüklenmesinde dağıtım anahtarlarının seçiminde Faaliyete Tabanlı Maliyetleme (FTM) yöntemi ve Analitik Hiyerarşi Prosesi (AHP) entegrasyonu en iyi dağıtım anahtarının seçiminde kullanaarak mamullere yüklenecek olan çevresel maliyet tutarlarını tespit etmişler ve yöntemin etkinliği yapılan uygulama ile de doğrulanmaya çalışılmıştır.

Lin (2012) yaptığı çalışmada; Kuzey Amerika, Avrupa, Latin Amerika, Asya ve Orta Doğu'dan birçok büyük uluslararası havayolu işletmesinin finansal performansına bakmıştır. Veri zarflama analizine dayanan sonuçlar; müşteri hizmetleri nitelik değerlendirmesi de dâhil olmak üzere işletme yönetiminin, faaliyete dayalı maliyetleme yönteminin benimsenmesiyle geliştirilebileceğini göstermiştir.

Akın (2013) çalışmasında mermer üreten bir işletme için Faaliyet Tabanlı Maliyetleme uygulaması gerçekleştirmiştir ve elde edilen sonuçları, geleneksel yöntem ile karşılaştırmıştır. Sonuçta FTM uygulaması ile elde edilen analiz değerlerinin, mevcut sistemden farklı ve objektif sonuçlar ortaya çıkardığı raporlanmıştır.

Ríos-Manríquez v.d. (2014) Faaliyet Tabanlı Maliyetleme'nin etkisini, ne kadar kullanıldığını ve özelliklerini analiz etmek ve değerlendirmek amacı ile Meksika'daki 180 KOBİ'den anket tekniği ile veri toplamışlardır. Çalışma sonucunda; bilgi eksikliğinden dolayı FTM'nin KOBİlerdeki geleneksel sistemlere olan nüfuzunun düşük olduğunu ve herhangi bir maliyetlendirme sistemi kullanmayan işletmelerin bulunduğunu göstermektedir. Meksika'daki KOBİ'lerin FTM'nin uyumluluğunu ve yararlılığını kabul ettikleri sonucuna ulaşmışlardir.

Kabinlapat ve Sutthachai (2017) çalışmalarında beş adımdan oluşan FTM'nin temel sürecini taze ve dondurulmuş tavuk işleme üretimine odaklanan bir gıda şirketine uygulamışlardır. Sonuçlar FTM ve şirketin mevcut maliyet sisteminin, özellikle de donmuş gıda ürünlerinde elde ettiği birim maliyetlerde önemli farklılıklar ortaya kayarak, şirketin mevcut maliyetlendirme sistemi içerisinde bozuk maliyet sistemi olasıllı̆ını öne sürmüşlerdir.

Yarıkkaya, Özekinci, Sargan, Erdoğan Durmuş ve Yıldız, (2017), sağlık yöneticileri ve Sosyal Güvenlik Kurumuna; mali planlama, kalite ve maliyet kontrolünde iyileştirmeler yapmalarını sağlamak amacıyla Okmeydanı Eğitim ve Araştırma Hastanesi Patoloji Anabilim Dalı tarafından kabul edilen histopatolojik incelemelerin maliyetlerini faaliyete dayalı maliyet yöntemini kullanılarak hesaplamışlardır. Birçok patoloji muayenesinin maliyetinin Sağlık Bakanlığı tarafından belirlenen maliyetlerden farklılık gösterdiğini belirtilen patoloji muayene tarifelerinin, muayenelerin gerçek masraflarını yansıtmadığı sonucuna ulaşmışlardır.

Faaliyet Tabanlı Maliyetleme için Analitik Hiyerarşi Prosesinin kullanılması hakkında yapılan eski tarihli çalışmalardan biri Partovi (1991)’ye aittir. Genel üretim giderlerinin, ürünlere dağıtılmasında AHP tekniğinin 


\section{M. Özçalıcı - A. Kaya 11/4 (2019) 3035-3050}

(FTM-AHP) uygulanması önerilmiş ve gerçek bir firmadan edinilen veri ile uygulama gerçekleştirilmiştir. Çalışmada bir uzman görüşüne yer verilmiştir. Bilgisayar ve telefon için kablo üreten bir işletmenin üç farklı ürünü için maliyet hesaplaması gerçekleştirilmiştir. Sonuçta önerilen yöntemin dağıtım anahtarları mevcut olmadığında kullanılabilecek bir yöntem olduğu ifade edilmektedir. Shashikumar, Sarkar ve Sanyal (2017) çalışmalarında üretim tesisi yerleşke alternatiflerinin değerlendirilmesinde FTM ve AHP tabanlı bir sistem uygulamışlardır. Sonuçta; beş alternatif arasından en iyi alternatifi belirledikleri raporlanmaktadır. Alternatif sayısı çoğaltıldığında bile modelin etkin bir şekilde sıralama gerçekleştireceği raporlanmaktadır. Da Rocha, SLoane ve Bassani (2005), medikal ekipman bakım hizmeti kararlarında kullanılmak üzere FTM ve AHP tabanlı bir sistem geliştirmişlerdir. Sonuçta alternatifleri performans ve maliyet grafiği üzerinde değerlendirmeye tabi tutmuşlardır. Angelis ve Lee (1996) ise stratejik yatırım analizinde FTM ve AHP tekniğini bir arada kullandıkları bir model önermişlerdir. AHP'nin hem finansal hem de finansal olmayan değişkenleri değerlendirebilmesine vurgu yapmışlardır.

Bu çalışmada; maliyetlerin dağıtılmasında kullanılacak sürücüler, Analitik Hiyerarşi Prosesi (AHP) yardımıyla belirlenmiştir. Bu amaçla; beş farklı uzman, dağıtım anahtarlarını belirlemek için değerlendirmelerde bulunmuşlardır. Değerlendirmeler arasındaki uzlaşı, geometrik ortalama ile hesaplanmıştır. Elde edilen sonuçlar işletmenin hâlihazırda uyguladığı geleneksel maliyet sisteminin sonuçları ile karşılaştırılmıştır.

\section{METODOLOJI}

Bu bölümde çalışmada kullanılan Faaliyet Tabanlı Maliyetleme ve Analitik Hiyerarşi Prosesi konuları hakkında özet bilgiler sunulacaktır.

\subsection{Faaliyet Tabanlı Maliyetleme}

FTM, kısaca, birim maliyetin belirlenmesinde, bireysel faaliyetlerin maliyet nesnesi olarak kullanılması olarak tanımlanabilir (Horngren v.d., 2015, s.955). FTM tekniği aşağıdaki gibi özetlenebilir (Tsai ve Kuo, 2004): Maliyet nesneleri (ürünler, üretim hatları, süreçler, müşteriler, piyasalar vb) faaliyetlere gereksinim duymaktadır ve faaliyetler de kaynak ihtiyacını ortaya çıkarmaktadır. FTM maliyetleri, maliyet nesnelerine atamak için iki aşamalı bir süreç kullanmaktadır. İlk aşamada, kaynak maliyetleri, kaynak sürücüleri yardımıyla faaliyet havuzunda bulunan faaliyetlere atanmaktadır. Kaynak sürücüleri, faaliyetlerin kaynakları ne düzeyde kullandığını belirleyen faktörlerdir. İkinci aşamada ise, faaliyet merkezlerinde toplanan maliyetler, faaliyet sürücüleri yardımıyla, maliyet nesnelerine atanmaktadır.

Geleneksel maliyetlendirme ile Faaliyet Tabanlı Maliyetleme yöntemi arasındaki fark şu şekilde açılanabilir (Büyükmirza, 2011, s.290): Geleneksel maliyetlendirme yönteminde üretim giderlerinin mamüller için yapıldığı varsayılmakta ve bu giderler ile mamuller arasında bağlantı kurulmaktadır. Faaliyet Tabanlı Maliyetlendirme yöntemine göre ise giderler mamuller için değil, faaliyetlerin yürütülmesi için yapılmaktadır. Dolayısıyla FTM yaklaşımında giderler önce faaliyetlere yüklenmekte ve her bir faaliyetin maliyeti hesaplanmaktadır. Daha sonra her faaliyetin maliyetinden mamullere o faaliyetten yararlanma derecelerine göre (dağıtım anahtarı veya sürücüler) pay verilmektedir (Büyükmirza, 2011, s.291).

Faaliyet Tabanlı Maliyetleme sistemi; stratejik, faaliyet kontrolü ve mamul grupları ile ilgili tüm kararların alınmasında maliyet bilgisini sağlayan ve bu faaliyetlerle ilgili maliyetleri mamullere ve/veya mamul gruplarına kullandıkları faaliyet oranında pay veren bir maliyet sistemidir (Unutkan, 2010, s.90).

FTM sisteminin temel amaçları ise; üretimde değer yaratmayan faaliyetlere ait maliyetleri ortadan kaldırmak veya en aza indirmek, yetersiz maliyet dağıtımından kaynaklanan yanlışlıkları ortadan kaldırmak, işletmenin faaliyet tüketimi, maliyet ve ilgi alanlarını tanımlayarak detaylı bilgi vermek, yöneticilere karar alma süreçlerinde kullanmak üzere doğru maliyet bilgileri sağlamaktır (Cengiz, 2011, s.93).

FTM sisteminin bazı avantaj ve dezavantajları bulunmaktadır. FTM'nin avantajları arasında; önemli miktara ulaşan endirekt maliyetlerin sadece birkaç maliyet havuzu yardımıyla dağıtılabilmesi, ürünlerin farklı düzeylerde kaynak kullanması, endirekt maliyetlerin birim maliyet haline getirilebilmesi, maliyetlerin hesaplanması konusundaki anlaşmazlıkları ortadan kaldırabilmesi sıralanabilir (Horngren v.d., 2015, s.189). Bunun yanı sıra, faaliyet sayısına karar verme, analizi yaparken çok fazla hesaplamaya ihtiyaç duyma ve hesaplamaların düzenli olarak güncellenme zorunluluğu gibi dezavantajları da bulunmaktadır (Horngren v.d., 2015, s.189). 


\subsection{Analitik Hiyerarşi Prosesi}

Analitik Hiyerarşi Prosesi (AHP) 1970'li yıllarda Wharton School of Business'da Thomas L. Saaty tarafından karmaşık çok kriterli karar verme problemlerinin çözümü için geliştirilmiştir. Analitik Hiyerarşi Prosesi genel bir ölçüm teorisidir (Saaty ve Vargas, 2012, s.3). Hem kesikli hem de sürekli değerlerden oluşan ikili karşılaştırmaları kullanmak suretiyle oran ölçeğinde değerler ortaya çıkarmaktadır. Analitik Hiyerarşi Prosesi aşağıdaki gibi özetlenebilir;

A matrisi, Formül (1)'deki gibi bir karşılaştırma matrisini temsil etsin.

$$
\boldsymbol{A}=\left[\begin{array}{ccc}
a_{11} & \ldots & a_{1 n} \\
\ldots & \ldots & \ldots \\
a_{n 1} & \ldots & a_{n n}
\end{array}\right]
$$

Geçerli bir AHP karşılaştırma matrisinde (A) $a_{x y}=1 / a_{(y x)}$ olmalıdır. Ayrıca ana köşegendeki değerler 1'e eşit olmalıdır. Matristeki satır sayısı sütun sayısına eşit olmalıdır. Ayrıca yapılan değerlendirmeler tutarlı olmalıdır. A ile gösterilen bir karşılaştırma matrisinde Formül (2)'deki koşul sağlanırsa tutarlı bir karşılaştırma yapılmış demektir.

$$
a_{i j} a_{j k}=a_{i k} \text {, her } i, j \text { ve } k \text { değeri için }
$$

Bazı durumlarda değerlendirme yapılırken tutarsız değerlendirme yapılmış olabilir. Bu nedenle AHP karşılaştırma matrislerinin ne düzeyde tutarsız olduklarının hesaplanması önem arz etmektedir. AHP karşılaştırma matrisinin tutarsızlık katsayısı (CR) Formül (3) yardımıyla hesaplanmaktadır (Taha, 2011, s,.552);

$$
\mathrm{CR}=\frac{\mathrm{CI}}{\mathrm{CR}}
$$

Formülde;

$\mathrm{CI}=\mathrm{A}$ matrisinin tutarsızlık indeksi

$$
\mathrm{CI}=\frac{\lambda_{\max }-\mathrm{n}}{\mathrm{n}-1}
$$

$\mathrm{RI}=\mathrm{A}$ matrisinin rassal tutarsızlı̆̆

$$
\mathrm{RI}=\frac{1.98(\mathrm{n}-2)}{\mathrm{n}}
$$

$\lambda_{\max }$ ifadesi sütun vektörü olan $A \bar{w}(\bar{w}, A$ matrisinin normalleştirilmiş değerlerini içeren sütun vektörüdür)'nin elemanları toplamına eşittir.

Eğer, CR $\leq 0.1$ ise matristeki tutarsızlık kabul edilebilir düzeydedir (Taha, 2011, s.553). Aksi durumda, karar verici değerlendirmeleri gözden geçirmelidir.

AHP tekniği; yatırım projelerinin değerlendirilmesi (Çevik ve Gökşen, 2016), performans değerlendirme formu tasarımı (Eraslan ve Algün, 2005), karar destek sistemi oluşturulması (Tüminçin, 2016), hazır giyim sektöründe en iyi işletme seçimi (Ayyar ve Arslan, 2013), personel seçimi (Bedir ve Eren, 2015) firmaların finansal performanslarının ölçümü (Karaoğlan ve Şahin, 2018), tedarikçi seçimi (Kazançoğlu ve Erhan, 2010), müşteri memnuniyeti (Dağsuyu, Dere ve Kokangül, 2016), portföy seçimi (Söylemez ve Koç, 2017), eğitim (Tamer, 2012), kuruluş yeri seçimi (Ar, Birdoğan ve Özdemir, 2014), tıpta uzmanlık alanı seçimi (Ömürbek, Tunca, Özcan, Yıldız, ve Karataş, 2016) gibi alanlarda uygulanmaktadır. AHP tekniğinin bazı avantaj ve dezavantajları mevcuttur. Avantajları arasında hesaplama adımlarının kolay olması, nicel ve nitel faktörleri göz önünde bulundurması, uzman deneyimlerini, bilgilerini, sezgilerini karar sürecine dâhil edebilmesi gibi maddeler sıralanabilir (Özbek, 2017, s.73-75). AHP sürecinin bazı dezavantajları ise öznel yargıları içermesi, karşılaştırma işlemlerinin zaman alması, uzman görüşüne ihtiyaç duyulması olarak sıralanabilir (Özbek, 2017, s.7375). 


\section{3. ÖNERILLEN MODEL}

Bu bölümde, önerilen model ve modelin uygulandığı işletme hakkında bilgi verilecektir.

\section{1. Çalışmada Uygulanan Model}

Çalışmada, Partovi (1991)'nin önerdiği model kullanılmıştır (Şekil 1). Yazar, FTM uygulamasında, sürücülerin belirlenmesi için AHP'nin kullanılabileceğini önermektedir. İlk olarak firma ile ilgili bilgiler bir araya getirilmiştir. Bu bilgiler arasında işletmenin satış ve üretim tutarları yer almaktadır. Daha sonra, işletmenin üretim süreci modellenmiştir. Bu aşamada; analizde kullanılacak maliyetler, faaliyetler ve ürünlerin neler olduğu belirlenmiştir. Daha sonra beş farklı uzman AHP formlarını doldurmuştur. Uzmanların görüşleri arasındaki uzlaşı, geometrik ortalama yardımıyla sağlanmıştır (Kuruüzüm ve Atsan, 2001; Dijkstra, 2013; Ömürbek ve Tunca, 2013; Ömürbek v.d, 2016). Endirekt giderler, tutarlı olan AHP karşılaştırma matrisleri yardımıyla faaliyetlere dağıtılmıştır. Faaliyet havuzunda toplanan giderler, ikinci aşamada yine AHP karşılaştırma matrislerini kullanmak suretiyle ürünlere dağıtılmıştır. Endirekt giderler ürünlere dağıtıldıktan sonra, ürün bazında takip edilen direkt giderler ile toplanmış ve toplam ve birim maliyet hesaplamaları gerçekleştirilmiştir.

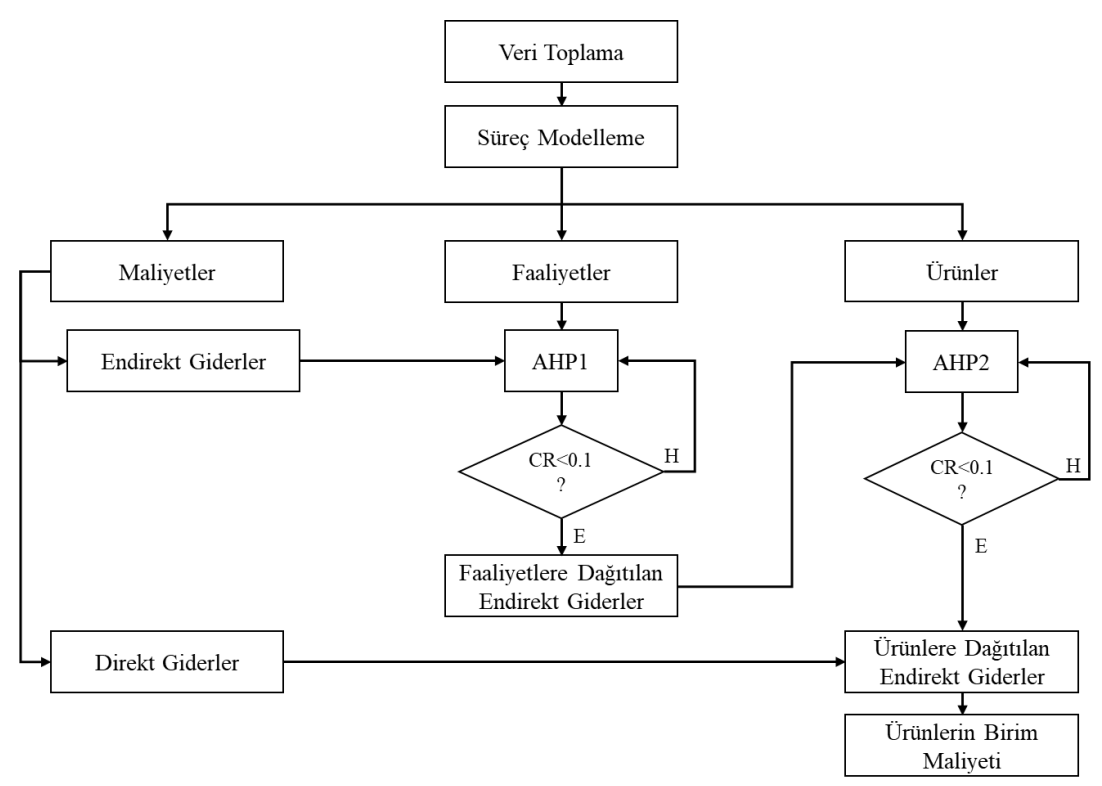

Şekil 1. Çalışmanın Modeli

\subsection{Veri Seti}

Çalışmada, Gaziantep Organize Sanayi Bölgesi'nde kayıtlı ve faaliyetlerine 1982 yılında bir şahıs işletmesi olarak başlamış bir limitet şirketin, 1 Ocak 2013 ve 31 Aralık 2013 tarihli dönemi inceleme altına alınmıştır. İncelenen dönemde işletmenin aktif büyüklüğü yaklaşık 13 milyon TL'dir. İşletme, 300 ton günlük ve 100.000 ton yıllık un üretim kapasitesine sahiptir. Yapılan görüşmelerde, işletmenin isminin gizli kalması talep edilmiştir. Bu nedenle de çalışmada şirket hakkında özel bilgilere yer verilmeyecektir.

Tablo 1. İşletmenin Faaliyetleri (Faaliyet Merkezleri)

\begin{tabular}{ccc}
\hline Kisaltma & Faaliyet İsmi \\
\hline F1 & Satın Alma ve Depolama \\
F2 & Buğdayın Yıanması \\
F3 & Buğdayın Tavlanması \\
F4 & Buğdayın Öğ̈̈tülmesi \\
F5 & Eleme İşlemleri \\
F6 & Ambalajlama \\
\hline
\end{tabular}

FTM'nin uygulanması için ihtiyaç duyulan maliyet bilgileri, işletmenin Finansal Durum, Finansal Performans Tabloları ile Yardımcı Defter kayıtlarından ve işletmenin muhasebe kayıtlarından sorumlu bir kişi ile yapılan görüşmelerden derlenmiştir. İşletmenin ana faaliyetleri üç grupta toplanmıştır. Bu gruplar; satın alma ve depolama faaliyeti, üretim faaliyet grubu ve ambalajlama faaliyetidir. Üretim faaliyetleri de kendi içinde dört alt 
faaliyetten oluşmaktadır. Bu üretim alt faaliyetleri; yıkama, tavlama, öğütme ve eleme faaliyetleridir. İşletmenin incelemeye alınan faaliyetleri Tablo 1.'de listelenmiştir.

Tablo 2.' de ürünlere ilişkin bilgiler yer almaktadır. İşletmenin ürettiği ürünler arasından, üç çeşidi incelemeye alınmıştır. İşletme, farklı nitelikte ürünler de üretmektedir. Örneğin; özel amaçlı un, kırık buğday ve buğday satışı da gerçekleştirmektedir. Ancak incelenen dönemlerde bu ürünlerin satış hacmi, toplam satış hacminin yaklaşık \%15'ini oluşturmaktadır. Bu ürünler, işletmenin faaliyetlerinde az yer kapladığından çalışma kapsamı dışında bırakılmıştır.

Tablo 2. Ürünlere İlişkin Bilgiler

\begin{tabular}{llc}
\hline Ürün Kodu & Niteliği & Açıklama \\
\hline TIP1 550 & Daha Beyaz & Pasta - Börek \\
TIP2 650 & Orta & Fırın, Somun, Pide, Günlük Ekmek \\
TIP3 850 & Daha Esmer & Daha Siyah Kepek Yoğunluklu \\
\hline
\end{tabular}

İşletme ürettiği ürünler için detaylı maliyet kaydı tutmamaktadır. Hâlihazırda ürünlerin birim maliyetleri geleneksel maliyet yöntemine göre hesaplanmaktadır. İşletme birim maliyetine direk ilk madde malzeme direkt işçilik ve genel üretim maliyetlerini katmaktadır. Birim maliyet hesaplanırken direk ilk madde ve malzeme maliyeti ile direk işçilik maliyetini mamullere yüklemektedir. Genel üretim giderleri hesaplanırken, endirekt gider toplamı, ürünlere, üretim miktarına $(\mathrm{kg})$ göre dağıtılmaktadır.

Yapılan görüşmeler sonucunda; ürün bazında izlenemeyen giderler (Endirekt Giderler): Elektrik Gideri, Su Gideri, Makine Bakım Gideri ve Diğer Giderler olmak üzere dört grupta toplanmıştır. Ürün bazında ekonomik olarak takip edilebilen giderler ise Direkt İşçilik Giderleri, Direkt İlk Madde Malzeme Gideri ve Direkt İlk Malzeme Gideri olmak üzere üç çeşittir. Dönem içerisindeki gider türleri ve tutarları Tablo 3'de sunulmuştur. Dönem içerisinde işletmenin endirekt giderlerinin payı toplam giderler içerisinde yaklaşık $\% 11,91^{\prime}$ lik payı kaplamaktadır, geri kalan $\% 88,09^{\prime} 11 \mathrm{k}$ pay ise direkt giderlere aittir.

Tablo 3. Direkt ve Endirekt Dönem Giderleri

\begin{tabular}{lcrr}
\hline \multicolumn{1}{c}{ Gider Türü } & Açıklama & Dönem Gideri (TL) & Yüzde (\%) \\
\hline \multirow{4}{*}{ Endirekt } & Elektrik Gideri & $2.589 .818,60$ & \\
& Su Gideri & $31.532,40$ & \\
& Tamir-Bakım & $155.047,80$ & \\
& Diğer Giderler & $12.678,91$ & \\
& Toplam Endirekt Giderler & $2.789 .077,71$ & 11,91 \\
\cline { 2 - 5 } Direkt & Direkt İşçilik Giderleri & $357.925,57$ & \\
& Direkt Illk Madde Gideri & $20.111 .241,82$ & \\
& Direkt Illk Malzeme Gideri & $160.611,68$ & \\
\cline { 2 - 4 } & Toplam Direkt Giderler & $20.629 .779,07$ & 88,09 \\
\hline Toplam & (Endirekt + Direkt) & $23.418 .856,78$ & 100 \\
\hline
\end{tabular}

Her faaliyet her gideri kullanmamaktadır. Tablo 4' de faaliyetlerin giderlerle ilişkilendirilmesi yer almaktadır. Tablo 4'de ilk sirada yer alan elektrik gideri ve son sırada yer alan diğer giderler her faaliyet ile ilgili iken, ikinci sırada yer alan su gideri; birinci, ikinci ve üçüncü faaliyet ile ilgilidir. Başka bir ifade ile su giderini satın alma, yıkama ve tavlama faaliyeti kullanmaktadır.

Tablo 4. Faaliyetler ve Gider Kalemleri

\begin{tabular}{|c|c|c|c|c|c|c|}
\hline & F1 & F2 & F3 & F4 & F5 & F6 \\
\hline Elektrik Gideri & + & + & + & + & + & + \\
\hline Su Gideri & + & + & + & & & \\
\hline Tamir Bakım Gideri & & + & + & + & + & + \\
\hline Diğer Giderler & + & + & + & + & + & + \\
\hline
\end{tabular}




\section{UYGULAMA}

Genel gider niteliğindeki giderlerin ürünlere dağıtılması iki aşamada gerçekleştirilmiştir. İlk olarak giderlerin, kaynak sürücüleri yardımıyla faaliyetlere yüklenmesi ve ikinci adımda da faaliyet havuzunda toplanan giderlerin, faaliyet sürücüleri yardımıyla ürünlere yüklenmesi aşamasıdır. Her iki aşamada da sürücüler AHP tekniği yardımıyla hesaplanmıştır. Çalışmanın uygulama aşamasında Özçalıcı (2017) tarafından MATLAB platformunda hazırlanan kodlar kullanılmıştır.

Çok Kriterli Karar Verme (ÇKKV) problemlerinde kriter ağırlıkları ve kullanılan yöntem problemin çözümüne doğrudan etki etmektedir (Durmuş ve Tayyar, 2017, s.65). Bu nedenle sadece bir uzmanın gerçekleştireceği değerlendirmeleri dikkate almak, sonuçların yanlı olmasına neden olacaktır. Çalışmada, beş farklı uzmanın değerlendirmeleri dikkate alınmıştır. Bu şekilde farklı görüşler bir araya getirilmiş ve görüşler arasında uzlaşı geometrik ortalama yardımıyla sağlanmıştır. İşletme faaliyetlerini yakından tanıyan ve aynı zamanda işletmenin muhasebesinden sorumlu olan iki uzman, işletmenin üretiminden sorumlu bir uzman, yönetim kademesinden bir uzman ve bir akademisyen AHP formlarını birbirlerinden bağımsız bir şekilde değerlendirmişlerdir. Her uzman, faaliyet havuzunda toplanan faaliyetlerin, gider havuzunda toplanan dört farklı gider türünü ne ölçüde kullandığını ikili karşılaştırmalar yardımıyla değerlendirmeye tabi tutmuştur. Uzmanların oluşturdukları AHP değerlendirme matrislerinin tutarlı olup olmadıkları kontrol edilmiştir. Bazı değerlendirme matrislerinin tutarsızlık katsayıları kabul edilen sınırın üzerinde çıkmıştır. Bu gibi durumlarda matrislerdeki değerlendirmeler, tutarsızlık katsayısı kabul edilebilir sınırın altına düşünceye kadar gözden geçirilmiştir. Sonuçta, her uzman, tutarlı ikili karşılaştırmaları içeren değerlendirme matrisleri oluşturmuştur.

\subsection{Giderlerin Faaliyetlere Yüklenmesi Süreci (I. Aşama) (Kaynak Sürücülerinin Belirlenmesi)}

$\mathrm{Bu}$ aşamada endirekt giderler faaliyetlere atanmaktadır. Bu atama işleminde kullanılacak sürücü değerleri, AHP değerlendirme matrisleri yardımıyla hesaplanmaktadır.

\subsubsection{Elektrik Giderlerin Faaliyetlere Yüklenmesi}

Elektrik gideri, firmanın abone olduğu elektrik dağıtım şirketinin söz konusu yıl için faturaladığı tutardır. Tablo 5'de, her bir faaliyetin elektrik giderini ne kadar kullandığına ilişkin beş farklı uzmanın gerçekleştirdiği AHP değerlendirmeleri ve bu değerlendirmelerin geometrik ortalamasını içeren uzlaşı değerleri yer almaktadir.

Tablo 5. Elektrik Giderlerinin Faaliyetlere Yüklenmesi

\begin{tabular}{cccccccc}
\hline & U1 & U2 & U3 & U4 & U5 & G.O. & \\
\hline F1 & $1 / 2$ & 1 & 1 & 1 & $1 / 2$ & 0,758 & F2 \\
F1 & $1 / 5$ & $1 / 4$ & $1 / 4$ & $1 / 5$ & $1 / 6$ & 0,211 & F3 \\
F1 & $1 / 9$ & $1 / 9$ & $1 / 9$ & $1 / 9$ & $1 / 9$ & 0,111 & F4 \\
F1 & $1 / 8$ & $1 / 8$ & $1 / 9$ & $1 / 8$ & $1 / 8$ & 0,122 & F5 \\
F1 & $1 / 7$ & $1 / 6$ & $1 / 7$ & $1 / 6$ & $1 / 7$ & 0,152 & F6 \\
F2 & $1 / 2$ & 1 & $1 / 2$ & $1 / 2$ & 1 & 0,660 & F3 \\
F2 & $1 / 8$ & $1 / 8$ & $1 / 8$ & $1 / 9$ & $1 / 8$ & 0,122 & F4 \\
F2 & $1 / 7$ & $1 / 7$ & $1 / 7$ & $1 / 8$ & $1 / 8$ & 0,135 & F5 \\
F2 & $1 / 5$ & $1 / 5$ & $1 / 4$ & $1 / 4$ & $1 / 5$ & 0,219 & F6 \\
F3 & $1 / 7$ & $1 / 6$ & $1 / 6$ & $1 / 6$ & $1 / 7$ & 0,157 & F4 \\
F3 & $1 / 5$ & $1 / 3$ & $1 / 3$ & $1 / 4$ & $1 / 4$ & 0,268 & F5 \\
F3 & $1 / 2$ & $1 / 2$ & $1 / 2$ & $1 / 2$ & $1 / 2$ & 0,500 & F6 \\
F4 & 2 & 1 & 2 & 2 & 3 & 1,888 & F5 \\
F4 & 5 & 5 & 4 & 5 & 5 & 4,782 & F6 \\
F5 & 2 & 1 & 1 & 1 & 2 & 1,320 & F6 \\
\hline CR & $\mathbf{0 , 0 6 4}$ & $\mathbf{0 , 0 6 2}$ & $\mathbf{0 , 0 3 3}$ & $\mathbf{0 , 0 5 1}$ & $\mathbf{0 , 0 8 5 2}$ & $\mathbf{0 , 0 4 4}$ & \\
\hline
\end{tabular}

Tablo 5'in en alt satırında ikili karşılaştırma matrislerinin tutarsızlık katsayıları yer almaktadır. Örneğin, birinci ve beşinci sırada yer alan uzmanlar, birinci sırada yer alan faaliyetin (F1),ikinci sırada yer alan faaliyete göre (F2) elektrik giderini 1/2 kat daha fazla kullandığını belirlemiştir (F1 = 0,5 F2). İkinci, üçüncü ve dördüncü uzman ise birinci ve ikinci faaliyetin elektrik giderini aynı oranlarda kullandığı yönünde değerlendirmede 
M. Özçalıcı - A. Kaya 11/4 (2019) 3035-3050

bulunmuştur (F1 = F2). Uzmanların birinci ve ikinci faaliyet için gerçekleştirdikleri bu değerlendirmelerin geometrik ortalaması alındığında $0,758\left(=\sqrt[5]{\left(\frac{1}{2}\right)(1)(1)(1)\left(\frac{1}{2}\right)}\right)$ değeri elde edilmektedir. Başka bir ifade ile uzmanların görüşleri arasında geometrik ortalama yardımıyla bir uzlaşı sağlandığında, elektrik giderini birinci faaliyetin, ikinci faaliyetin 0,758 katı kadar kullandığı değerlendirmesi ortaya çıkmaktadır (F1=0,758 F2).

Çalışma boyunca Tablo 5' dekine benzer farklı tablolar oluşturulmuştur. Tablolarda uzmanların yaptıkları ikili karşılaştırma değerleri özet halinde sunulmuştur. Tablolarda, tutarsızlık değerleri ve sürücü katsayılarının belirlenmesinde benzer hesaplamalar gerçekleştirilmektedir. Her hesaplamaya çalışmada yer vermek çalışmanın hacmini yükseltecektir. Bu nedenle de sadece bir hesaplama örneğinin detaylarını aşağıda sunulmuştur.

İlk olarak tutarsızlık katsayısının hesaplanması açıklanacaktır. Elektrik giderinin birinci uzman tarafından değerlendirilmesine ilişkin AHP değerlendirmelerinin matris formu Formül (5)'de gösterildiği gibidir. Bu matris Formül (1)'deki A matrisi ile temsil edilmektedir. En alt satırda sütun toplamları hesaplanmıştır.

\begin{tabular}{|c|c|c|c|c|c|c|}
\hline & $F$ & $F 2$ & $F 3$ & $F$ & $F 5$ & $F 6$ \\
\hline$F 1$ & $\lceil 1$ & $1 / 2$ & $1 / 5$ & $1 / 9$ & $1 / 8$ & $1 / 7$ \\
\hline 42 & 2 & 1 & $1 / 2$ & $1 / 8$ & $1 / 7$ & $1 / 5$ \\
\hline$F 3$ & 5 & 2 & 1 & $1 / 7$ & $1 / 5$ & $1 / 2$ \\
\hline 74 & 9 & 8 & 7 & 1 & 2 & 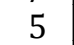 \\
\hline$F 5$ & 8 & 7 & 5 & $1 / 2$ & 1 & 2 \\
\hline$F 6$ & 7 & 5 & 2 & $1 / 5$ & $1 / 2$ & \\
\hline
\end{tabular}

$$
32 \quad 23,50 \quad 15,70 \quad 2,08 \quad 3,97 \quad 8,84
$$

Bu matriste her bir değeri sütun toplamına bölmek suretiyle normalleştirilmiş matris Formül (6)'daki gibi hesaplanmaktadır. Son sütunda ise normalleştirilmiş değerlerin satır ortalamaları yer almaktadır. Satır ortalamaları, Formül (4)'ün hesaplanmasında kullanılacak $\overline{\mathbf{w}}$ vektörüdür.

\begin{tabular}{|c|c|c|c|c|c|c|c|}
\hline & $F 1$ & 2 & $F 3$ & $F 4$ & 5 & 86 & $\overline{\boldsymbol{w}}$ \\
\hline & & & & & & & \\
\hline & & & & & & & \\
\hline & & 0,0 & 0,0 & 0,07 & 0,05 & & \\
\hline & 0 & 0 & 0,4 & 0,48 & 0,50 & 0, & 0,4 \\
\hline & & 0,3 & 0,3 & 0,24 & 0,25 & 0 , & 0,26 \\
\hline & & 0,21 & 0,13 & 0,10 & 0,13 & 0,1 & 0,1 \\
\hline
\end{tabular}

Tutarsızlık katsayısının hesaplanmasında kullanılacak olan $\lambda_{\max }$ değeri, Amatrisi ile $\overline{\mathrm{w}}$ vektörünün matris çarpımı ile hesaplanmaktadır (Formül (7)).

$$
\left[\begin{array}{cccccc}
1 & 1 / 2 & 1 / 5 & 1 / 9 & 1 / 8 & 1 / 7 \\
2 & 1 & 1 / 2 & 1 / 8 & 1 / 7 & 1 / 5 \\
5 & 2 & 1 & 1 / 7 & 1 / 5 & 1 / 2 \\
9 & 8 & 7 & 1 & 2 & 5 \\
8 & 7 & 5 & 1 / 2 & 1 & 2 \\
7 & 5 & 2 & 1 / 5 & 1 / 2 & 1
\end{array}\right] \times\left[\begin{array}{c}
0,03 \\
0,04 \\
0,08 \\
0,44 \\
0,26 \\
0,15
\end{array}\right]=\left[\begin{array}{c}
0,17 \\
0,26 \\
0,49 \\
2,86 \\
1,70 \\
0,94
\end{array}\right]
$$

$\lambda_{\text {max }}$ değeri Ā̄ çarpımındaki değerlerin toplamı olarak Formül (8)'deki gibi hesaplanmaktadır.

$$
\lambda_{\max }=0,17+0,26+0,49+2,86+1,70+0,94=6,42
$$

Formül (3) - (4) yardımıyla tutarsızlık oranı aşağıdaki gibi hesaplanmıştır.

$$
C R=\frac{(6,42-6) /(6-1)}{1,98 *(6-2) / 6}=0,064
$$


M. Özçalıcı - A. Kaya 11/4 (2019) 3035-3050

Hesaplama detaylarına yer verilen ikinci husus ise sürücülerin belirlenmesidir. Sürücülerin belirlenmesinde geometrik ortalama değerleri kullanılmaktadır. Elektrik gideri için kaynak sürücüsünün belirlenmesinde Tablo 5'in sonunda yer alan geometrik ortalama değerleri kullanılmaktadır. İlk olarak Formül (1)'de yer alan A matrisi Formül (10)'daki gibi oluşturulmaktadır. Son satırda, sütun ortalamaları yer almaktadır.

\begin{tabular}{|c|c|c|c|c|c|c|}
\hline & $F 1$ & $F 2$ & $F 3$ & $F 4$ & $F 5$ & $F 6$ \\
\hline$F 1$ & 1 & 0,76 & 0,21 & 0,11 & 0,12 & $0,15]$ \\
\hline$F 2$ & 1,132 & 1 & 0,66 & 0,12 & 0,14 & 0,22 \\
\hline$F 3$ & 4,74 & 1,52 & 1 & 0,16 & 0,27 & 0,50 \\
\hline$F 4$ & 9 & 8,19 & 6,38 & 1 & 1,89 & 4,78 \\
\hline$F 5$ & 8,19 & 7,38 & 3,73 & 0,53 & 1 & 1,32 \\
\hline$F 6$ & L 6,58 & 4,57 & 2,00 & 0,21 & 0,76 & 1 ] \\
\hline & ,83 & 23,42 & 13,9 & 2,13 & 4,18 & 7,9 \\
\hline
\end{tabular}

A matrisindeki her bir değer sütun toplamına bölünmek suretiyle Formül (11)'deki gibi normalleştirilmektedir. Son olarak normalleştirilmiş matristeki her bir satırın ortalaması hesaplanmaktadır $(\bar{w})$. Elektrik giderinin faaliyetlere dağıtılmasında kullanılacak sürücüler bu satır ortalamalarıdır. Bu değerler toplu olarak Tablo 9'de sunulmuştur.

\begin{tabular}{|c|c|c|c|c|c|c|c|}
\hline & $F 1$ & $F 2$ & $F 3$ & $F 4$ & $F 5$ & $F 6$ & \\
\hline$F 1$ & {$[0,03$} & 0,043 & 0,02 & 0,05 & 0,03 & $0,02\rceil$ & 0,03 \\
\hline$F 2$ & 0,04 & 0,04 & 0,05 & 0,06 & 0,03 & 0,03 & 0,04 \\
\hline$F 3$ & 0,15 & 0,06 & 0,07 & 0,07 & 0,06 & 0,06 & 0,08 \\
\hline$F 4$ & 0,29 & 0,35 & 0,46 & 0,47 & 0,45 & 0,60 & 0,44 \\
\hline$F 5$ & 0,27 & 0,32 & 0,27 & 0,25 & 0,24 & 0,17 & 0,25 \\
\hline$F 6$ & {$[0,21$} & 0,20 & 0,14 & 0,10 & 0,18 & $0,13]$ & 0,16 \\
\hline
\end{tabular}

\subsubsection{Su Giderlerin Faaliyetlere Yüklenmesi}

Su gideri ise, söz konusu yıl içerisinde, firmaya gönderilen su faturalarının toplamından oluşmaktadır. Her bir faaliyetin su giderini ne kadar kullandığına ilişkin değerlendirmeler, uzman görüşleri arasında geometrik ortalama yardımıyla sağlanan uzlaşı değerleri ve ikili karşılaştırma matrislerinin tutarsızlık değerleri Tablo 6.'da yer almaktadir.

Tablo 6. Su Giderinin Faaliyetlere Yüklenmesi

\begin{tabular}{cccccccc}
\hline & U1 & U2 & U3 & U4 & U5 & G.O. & \\
\hline F1 & 1 & $1 / 2$ & $1 / 2$ & $1 / 2$ & 1 & 0,660 & F2 \\
F1 & 4 & 4 & 4 & 3 & 5 & 3,949 & F3 \\
F2 & 9 & 9 & 8 & 8 & 9 & 8,586 & F3 \\
\hline CR & $\mathbf{0 , 0 7 5}$ & $\mathbf{0 , 0 0 2}$ & $\mathbf{0 , 0 0}$ & $\mathbf{0 , 0 1 0}$ & $\mathbf{0 , 0 3 9}$ & $\mathbf{0 , 0 1 5}$ & \\
\hline
\end{tabular}

\subsubsection{Tamir-Bakım Giderlerin Faaliyetlere Yüklenmesi}

Tamir-bakım giderleri firmanın söz konusu yıl boyunca gerçekleştirilen yedek parça, tamir ve bakım harcamalarından oluşmaktadır. Her bir faaliyetin tamir-bakım giderinden ne düzeyde yararlandığını belirlemek için gerçekleştirilen değerlendirmeler Tablo 7.'de yer almaktadır. Tablo 7.'de beş farklı uzman görüşü ve bu görüşler yardımıyla hesaplanan geometrik ortalamanın yanı sıra, her bir değerlendirme matrisinin tutarsızlık değerleri de yer almaktadır.

Tablo 7. Tamir-Bakım Giderinin Faaliyetlere Yüklenmesi

\begin{tabular}{cccccccc}
\hline & U1 & U2 & U3 & U4 & U5 & G.O. & \\
\hline F2 & $1 / 5$ & $1 / 6$ & $1 / 6$ & $1 / 4$ & $1 / 2$ & 0,234 & F3 \\
F2 & $1 / 2$ & 1 & $1 / 4$ & $1 / 2$ & $1 / 3$ & 0,461 & F4 \\
F2 & 1 & 6 & 6 & 4 & 2 & 3,104 & F5 \\
F3 & 1 & 2 & 2 & 1 & 3 & 1,644 & F4 \\
F3 & 8 & 9 & 9 & 9 & 9 & 8,790 & F5 \\
F4 & 5 & 7 & 8 & 9 & 4 & 6,320 & F5 \\
\hline CR & $\mathbf{0 , 0 4 8}$ & $\mathbf{0 , 0 6 9}$ & $\mathbf{0 , 0 8 6}$ & $\mathbf{0 , 0 3 0}$ & $\mathbf{0 , 0 5 6}$ & $\mathbf{0 , 0 0 5}$ & \\
\hline
\end{tabular}




\subsubsection{Diğer Giderlerin Faaliyetlere Yüklenmesi}

Diğer gider kaleminde ise, ürün bazında ekonomik olarak izlenemeyen muhtelif üretim giderleri yer almaktadır. Her bir faaliyetin, diğer gider kalemini kullanma düzeylerine ilişkin uzmanların ikili karşılaştırma değerleri, bu değerlerin geometrik ortalaması ve her bir değerlendirme matrisi için tutarsızlık değerleri Tablo 8.'deki gibidir.

Tablo 8. Diğer Giderinin Faaliyetlere Yüklenmesi

\begin{tabular}{cccccccc}
\hline & U1 & U2 & U3 & U4 & U5 & G.O. & \\
\hline F1 & 8 & 3 & 9 & 8 & 6 & 6,355 & F2 \\
F1 & 6 & 6 & 6 & 4 & 8 & 5,860 & F3 \\
F1 & 4 & 9 & 1 & 3 & 1 & 2,551 & F4 \\
F1 & 2 & 9 & 7 & 4 & 8 & 5,261 & F5 \\
F1 & $1 / 3$ & 2 & 2 & $1 / 2$ & 2 & 1,059 & F6 \\
F2 & $1 / 2$ & 1 & $1 / 4$ & $1 / 7$ & 1 & 0,447 & F3 \\
F2 & $1 / 4$ & 5 & $1 / 6$ & $1 / 4$ & $1 / 2$ & 0,482 & F4 \\
F2 & $1 / 6$ & 7 & 1 & $1 / 2$ & 3 & 1,118 & F5 \\
F2 & $1 / 9$ & 1 & $1 / 7$ & $1 / 9$ & $1 / 3$ & 0,226 & F6 \\
F3 & $1 / 2$ & 2 & 1 & 2 & $1 / 4$ & 0,871 & F4 \\
F3 & $1 / 5$ & 3 & 2 & 4 & 2 & 1,572 & F5 \\
F3 & $1 / 7$ & $1 / 3$ & $1 / 3$ & 1 & $1 / 4$ & 0,331 & F6 \\
F4 & 1 & 1 & 4 & 2 & 6 & 2,169 & F5 \\
F4 & $1 / 5$ & $1 / 5$ & 1 & $1 / 7$ & 1 & 0,356 & F6 \\
F5 & $1 / 4$ & $1 / 9$ & $1 / 5$ & $1 / 7$ & $1 / 8$ & 0,158 & F6 \\
\hline CR & 0,056 & 0,030 & 0,049 & 0,071 & 0,027 & 0,014 & \\
\hline
\end{tabular}

4.1.5. AHP Skorları İle Oluşturulan Dağıtım Anahtarlarının Toplu Gösterimi

Tablo 9'da, Tablo 5 ile Tablo 7 arasındaki tablolarda yer alan geometrik ortalama değerlerini kullanmak suretiyle hesaplanan AHP skorları topluca raporlanmıştır. Bu skorlar aynı zamanda faaliyet sürücüleridir. Tablo 9'daki değerlendirmelere göre, elektrik giderini en çok dördüncü faaliyet (buğdayın öğütülmesi) tüketmektedir. Elektrik giderini en az tüketen faaliyet ise birinci sırada yer alan satın alma ve depolama faaliyetidir. Su giderinden en çok pay alan faaliyet, ikinci sırada yer alan buğdayın yıkanması faaliyeti (F2) iken en az pay alan faaliyet üçüncü sırada yer alan buğdayın tavlanması faaliyetidir (F3).Tamir-bakım giderini en çok kullanan ilk üç faaliyet sırasıyla; F4, F5 ve F3'tir. F2 ve F6 faaliyetleri ise en düşük kullanım oranlarına sahip faaliyetlerdir. Diğer gider kalemini en çok kullanan faaliyet birinci sırada yer alan satın alma ve depolama faaliyetidir (F1). En az kullanan faaliyet ise beşinci sırada yer alan eleme işlemleridir.

Tablo 9. Dağıtım Anahtarları (AHP Skorları - Faaliyet Sürücüleri)

\begin{tabular}{ccccc}
\hline & Elektrik & Su & Tamir-Bakım & Diğer \\
\hline F1 & 0,030 & 0,341 & 0,000 & 0,360 \\
F2 & 0,042 & 0,582 & 0,063 & 0,058 \\
F3 & 0,082 & 0,077 & 0,132 & 0,096 \\
F4 & 0,437 & 0,000 & 0,467 & 0,119 \\
F5 & 0,250 & 0,000 & 0,290 & 0,056 \\
F6 & 0,160 & 0,000 & 0,046 & 0,311 \\
\hline Toplam & 1 & 1 & 1 & 1 \\
\hline
\end{tabular}

\subsubsection{AHP Skorları İle Oluşturulan Dağıtım Tutarlarının Toplu Gösterimi (TL)}

Endirekt giderler, Tablo 9'daki AHP ağırlıklarını kullanmak suretiyle, faaliyetlere dağıtılmıştır. Sonuçlar Tablo 10.'daki gibidir. Bu değerler, Tablo 9.'daki dağıtım anahtarları ile Tablo. 3'deki giderlerin tutar değerlerin çarpılması ile elde edilmiştir. Tablodaki değerlere göre dağıtılacak endirekt giderler arasında en yüksek yeri \%92,86 ile elektrik gideri kaplamaktadır. Büyüklüklerine göre diğer giderler ise sırasıyla; tamir-bakım, su ve diğer giderlerdir. Endirekt giderlerden ilk üç sırada en fazla pay alan faaliyetler sırasıyla; buğdayın öğütülmesi, eleme ve ambalajlama faaliyetleridir. Endirekt giderlerden en az pay alan son üç faaliyet ise sırasıyla buğday tavlama, buğdayın yıkanması ve satın alma ve depolama faaliyetleridir. 
M. Özçalıc1 - A. Kaya 11/4 (2019) 3035-3050

Tablo 10. Endirekt Giderlerin Faaliyetlere Yüklenmesi

\begin{tabular}{lrrrrrrrr}
\hline & \multicolumn{1}{c}{ F1 } & \multicolumn{1}{c}{ F2 } & \multicolumn{1}{c}{ F3 } & F4 & \multicolumn{1}{c}{ F5 } & \multicolumn{1}{c}{ F6 } & Toplam (TL) & Yüzde (\%) \\
\hline Elektrik & 77.864 & 107.879 & 211.803 & 1.131 .010 & 648.141 & 413.120 & 2.589 .818 & 92,86 \\
Su & 10.766 & 18.338 & 2.427 & 0,00 & 0,00 & 0,00 & 31.532 & 1,13 \\
Tamir-Bakım & 0,00 & 9.841 & 20.517 & 72.453 & 45.033 & 7.201 & 155.047 & 5,56 \\
Diğer Giderler & 4.565 & 731 & 1.217 & 1.510 & 710 & 3.943 & 12.678 & 0,45 \\
Toplam (TL) & 93.196 & 136.790 & 235.965 & 1.204 .974 & 693.884 & 424.266 & 2.789 .077 & \\
\hline Yüzde (\%) & $\mathbf{3 , 3 4}$ & $\mathbf{4 , 9}$ & $\mathbf{8 , 4 6}$ & $\mathbf{4 3 , 2}$ & $\mathbf{2 4 , 8 8}$ & $\mathbf{1 5 , 2 1}$ & & \\
\hline
\end{tabular}

4.2. Faaliyet Havuzlarında Toplanan Giderlerin Ürünlere Yüklenmesi (II. Aşama) (Faaliyet Sürücülerinin Belirlenmesi)

Bu aşamada yine uzman görüşünden faydalanmak suretiyle her bir ürünün faaliyetleri ne düzeyde kullandığ1 AHP tekniği yardımıyla belirlenmiştir. Başka bir ifade ile faaliyet sürücülerinin belirlenmesi de kaynak sürücülerinin belirlenmesinde olduğu gibi uzman görüşleri doğrultusunda belirlenmiştir. Tablo 11'de ürünlerin faaliyetleri ne düzeyde kullandığına ilişkin uzman görüşlerine topluca yer verilmiştir.

Tablo 11. Faaliyet Sürücüleri Uzman Değerlendirmeleri

\begin{tabular}{|c|c|c|c|c|c|c|c|}
\hline \multicolumn{8}{|c|}{ Satın Alma ve Depolama Faaliyetinde Biriken Maliyetlerin Ürünlere Yüklenmesi } \\
\hline & U1 & $\mathrm{U} 2$ & U3 & $\mathrm{U} 4$ & U5 & G.O. & \\
\hline Ü1 & $1 / 3$ & $1 / 2$ & $1 / 2$ & $1 / 2$ & $1 / 5$ & 0,384 & Ü2 \\
\hline Ü1 & 5 & 1 & 3 & 5 & 2 & 2,724 & Ü3 \\
\hline$\ddot{\mathrm{U} 2}$ & 9 & 3 & 5 & 9 & 8 & 6,274 & Ü3 \\
\hline CR & 0,034 & 0,017 & 0,004 & 0,001 & 0,008 & 0,002 & \\
\hline \multicolumn{8}{|c|}{ Buğday Yıkama Faaliyetinde Biriken Maliyetlerin Ürünlere Yüklenmesi } \\
\hline & U1 & U2 & U3 & $\mathrm{U} 4$ & U5 & G.O. & \\
\hline$\ddot{\text { Ü1 }}$ & $1 / 4$ & $1 / 3$ & $1 / 2$ & $1 / 2$ & $1 / 4$ & 0,349 & $\ddot{\mathrm{U} 2}$ \\
\hline Ü1 & 1 & 1 & 1 & 4 & 1 & 1,320 & Ü3 \\
\hline Ü2 & 5 & 6 & 4 & 7 & 7 & 5,674 & Ü3 \\
\hline CR & 0,007 & 0,063 & 0,053 & 0,002 & 0,045 & 0,021 & \\
\hline \multicolumn{8}{|c|}{ Buğday Tavlama Faaliyetinde Biriken Maliyetlerin Ürünlere Yüklenmesi } \\
\hline & U1 & $\mathrm{U} 2$ & U3 & $\mathrm{U} 4$ & U5 & G.O. & \\
\hline Ü1 & $1 / 5$ & $1 / 3$ & $1 / 2$ & $1 / 2$ & $1 / 3$ & 0,354 & ப̈2 \\
\hline Ü1 & 4 & 3 & 2 & 5 & 4 & 3,438 & Ü3 \\
\hline Ü2 & 9 & 6 & 5 & 7 & 8 & 6,853 & Ü3 \\
\hline CR & 0,095 & 0,021 & 0,006 & 0,015 & 0,021 & 0,015 & \\
\hline \multicolumn{8}{|c|}{ Buğday Öğütme Faaliyetinde Biriken Maliyetlerin Ürünlere Yüklenmesi } \\
\hline & U1 & $\mathrm{U} 2$ & U3 & $\mathrm{U} 4$ & U5 & G.O. & \\
\hline Ü1 & $1 / 4$ & $1 / 3$ & $1 / 2$ & $1 / 3$ & $1 / 3$ & 0,341 & Ü2 \\
\hline Ü1 & 4 & 4 & 4 & 5 & 3 & 3,949 & Ü3 \\
\hline Ü2 & 9 & 6 & 9 & 9 & 8 & 8,106 & Ü3 \\
\hline CR & 0,047 & 0,060 & 0,002 & 0,034 & 0,002 & 0,016 & \\
\hline \multicolumn{8}{|c|}{ Eleme Faaliyetinde Biriken Maliyetlerin Ürünlere Yüklenmesi } \\
\hline & U1 & U2 & U3 & $\mathrm{U} 4$ & U5 & G.O. & \\
\hline Ü1 & $1 / 2$ & $1 / 3$ & $1 / 2$ & $1 / 3$ & $1 / 3$ & 0,392 & Ü2 \\
\hline Ü1 & 1 & 2 & 4 & 4 & 4 & 2,639 & Ü3 \\
\hline Ü2 & 2 & 4 & 5 & 9 & 8 & 4,919 & Ü3 \\
\hline CR & 0,00 & 0,019 & 0,025 & 0,011 & 0,021 & 0,012 & \\
\hline \multicolumn{8}{|c|}{ Ambalajlama Faaliyetinde Biriken Maliyetlerin Ürünlere Yüklenmesi } \\
\hline & U1 & $\mathrm{U} 2$ & U3 & $\mathrm{U} 4$ & U5 & G.O. & \\
\hline Ü1 & $1 / 2$ & $1 / 3$ & $1 / 5$ & $1 / 3$ & $1 / 3$ & 0,326 & Ü2 \\
\hline Ü1 & 7 & 4 & 2 & 1 & 4 & 2,952 & Ü3 \\
\hline Ü2 & 9 & 7 & 8 & 5 & 8 & 7,259 & Ü3 \\
\hline CR & 0,023 & 0,037 & 0,008 & 0,033 & 0,021 & 0,006 & \\
\hline
\end{tabular}


M. Özçalıcı - A. Kaya 11/4 (2019) 3035-3050

Tablo 11'de yer alan uzman değerlendirmelerinden yola çıkmak suretiyle faaliyet sürücüleri hesaplanmış ve hesaplanan sürücü değerleri Tablo 12 'de sunulmuştur.

Tablo 12. Dağıtım Anahtarları (AHP Skorları - Faaliyet Sürücüleri)

\begin{tabular}{lrrrrrr}
\hline & S. Alma ve Dep. & \multicolumn{1}{c}{ Yıkama } & \multicolumn{1}{c}{ Tavlama } & Öğ̈̈tme & \multicolumn{1}{c}{ Eleme } & Ambalajlama \\
\hline Ü1 & 0,258 & 0,204 & 0,261 & 0,258 & 0,270 & 0,238 \\
Ü2 & 0,644 & 0,662 & 0,653 & 0,668 & 0,617 & 0,675 \\
Ü3 & 0,099 & 0,135 & 0,086 & 0,074 & 0,114 & 0,087 \\
\hline
\end{tabular}

Tablo 13.'de ise endirekt giderlerin ürünlere faaliyet sürücüleri yardımılla yüklenmesi sonucu ürünlerde biriken tutarlar yer almaktadır. Örneğin ürün 1'in satın alma ve depolamadan aldığı pay 24.011,72 değeri, Tablo 12'deki 0,258 ile Tablo 10.'daki 93.196,32 değerinin çarpımı ile hesaplanmıştır (Çalışma boyunca tablodaki değerlerde yuvarlama yapılmıştır. Katsayılar üç haneye ve TL cinsinden tutarlar iki ondalıklı haneye yuvarlanmıştır. Yuvarlama yapılmadığ değerler 93.196,32172 × 0,257646622 = 24.011,71747398). Bu dağıtım işlemine göre ürün 2, faaliyetleri, \% 65,41 oranında kullanmak suretiyle en çok kullanan ürün olmaktadır. Ürün 3 ise faaliyetleri \% 9,05 oranında kullanmıştır.

Tablo 13. Faaliyet Havuzundan Ürünlere Dağıtılan Endirekt Gider Tutarları

\begin{tabular}{lrrrr}
\hline & \multicolumn{1}{c}{ Ürün 1 } & \multicolumn{1}{c}{ Ürün 2 } & \multicolumn{1}{c}{ Ürün 3 } & \multicolumn{1}{c}{ Toplam (TL) } \\
\hline Satın Alma ve Depolama & $24.011,72$ & $59.997,94$ & $9.186,67$ & $93.196,33$ \\
Buğdayın Yıkanması & $27.839,67$ & $90.499,28$ & $18.451,83$ & $136.790,78$ \\
Buğdayın Tavlanması & $61.617,31$ & $154.171,24$ & $20.176,89$ & $235.965,44$ \\
Buğdayın Öğ̈̈tülmesi & $311.096,03$ & $804.963,10$ & $88.914,91$ & $1.204 .974,04$ \\
Eleme İșlemleri & $187.018,12$ & $428.063,47$ & $78.803,36$ & $693.884,95$ \\
Ambalajlama & $100.880,14$ & $286.582,65$ & $36.803,40$ & $424.266,19$ \\
\hline Toplam (TL) & $712.462,99$ & $1.824 .277,68$ & $252.337,06$ & $2.789 .077,73$ \\
\hline Yüzde (\%) & 25,54 & 65,41 & 9,05 & \\
\hline
\end{tabular}

Tablo14.'de FTM-AHP yöntemi ile birim maliyet hesabı yer almaktadır. İlk sütunda FTM-AHP tekniği ile endirekt dağıtım tutarları yer almaktadır. Sonraki üç sütunda direkt giderlerin dağıtımı yer almaktadır. Beşinci sütunda direkt giderlerin toplamı, altıncı sütunda ise endirekt ve direkt giderlerin toplamı yer almaktadır. Nihai olarak üretim miktarlarının ve toplam maliyetin üretim miktarlarına bölümü ile hesaplanan birim maliyet sütunu yer almaktadır. Tablo 14'e göre FTM-AHP tekniği ile ürünlerin maliyeti sırasıyla 1,36 TL, 1,11 TL ve 0,66 TL olarak hesaplanmıştır.

Tablo 14. FTM birim maliyet hesaplama tablosu (Küsuratlar kullanılmamıştır)

\begin{tabular}{|c|c|c|c|c|c|c|c|}
\hline & Endirekt Gdr & \multicolumn{3}{|c|}{ Direkt Giderler } & \multirow[b]{2}{*}{$\begin{array}{l}\text { Endirekt+Di- } \\
\text { rekt (TL) }\end{array}$} & \multirow[b]{2}{*}{$\begin{array}{l}\text { Üretim mik- } \\
\operatorname{tarı}(\mathrm{kg})\end{array}$} & \multirow[b]{2}{*}{$\begin{array}{l}\text { Birim Mali- } \\
\text { yet (TL/kg) }\end{array}$} \\
\hline & $\begin{array}{l}\text { FTM-AHP ile } \\
\text { Dağıtım }\end{array}$ & D.i. & D.I.M. & D.I.MLZ & & & \\
\hline Ü1 & 712.463 & 34.589 & 1.999 .094 & 17.035 & 2.763 .182 & 2.029 .050 & 1,36 \\
\hline Ü2 & 1.824.277 & 291.519 & 16.392 .746 & 143.575 & 18.652 .118 & 16.780 .850 & 1,11 \\
\hline \multirow[t]{2}{*}{ Ü3 } & 252.337 & 31.816 & 1.719 .400 & 0,00 & 2.003 .554 & 3.034 .250 & 0,66 \\
\hline & & & & & 23.418 .855 & & \\
\hline
\end{tabular}

Tablo $15^{\prime}$ de ise geleneksel yönteme göre birim maliyetler yer almaktadır. İşletme hâlihazırda endirekt giderlerin dağıtımı için üretim miktarlarını kullanmaktadır. Her bir ürüne üretildiği miktar oranında endirekt giderlerden pay düşmektedir. Son sütunda ise geleneksel yönteme göre birim maliyetler yer almaktadır.

Tablo 15. Geleneksel Yönteme Göre Birim Maliyet Hesaplama (Küsuratlar kullanılmamıştır)

\begin{tabular}{lrrrrrr}
\hline & $\begin{array}{c}\text { Üretim Miktar- } \\
\text { ları }(\mathbf{k g})\end{array}$ & \multicolumn{1}{c}{$\begin{array}{c}\text { Dağıtım } \\
\text { Anahtarı }\end{array}$} & $\begin{array}{c}\text { Endirekt Gi- } \\
\text { derler }\end{array}$ & $\begin{array}{c}\text { Direkt Gider } \\
\text { Toplamı }\end{array}$ & \multicolumn{1}{c}{$\begin{array}{c}\text { Toplam } \\
\text { (TL) }\end{array}$} & $\begin{array}{c}\text { Birim Maliyet } \\
\text { (TL/kg) }\end{array}$ \\
\hline Ü1 & 2.029 .050 & 0,093 & 259.070 & 2.050 .719 & 2.309 .790 & 1,138 \\
Ü2 & 16.780 .850 & 0,768 & 2.142 .591 & 16.827 .841 & 18.970 .432 & 1,130 \\
Ü3 & 3.034 .250 & 0,139 & 387.415 & 1.751 .217 & 2.138 .632 & 0,705 \\
\cline { 2 - 4 } & 21.844 .150 & & & & & \\
\hline
\end{tabular}


Tablo 13 ve Tablo 14' de yer alan sonuçlara göre FTM-AHP tekniği ile Ürün 1'in maliyeti 1,36 TL olarak hesaplanmaktadır. Ayn ürün için halihazırda hesaplanan birim maliyet ise 1,14 TL dir. FTM-AHP tekniği ile ürün 1 için birim maliyet \%19,30 $(=(1,36-1,14) / 1,14)$ oranında daha yüksek hesaplanmıştır. Ürün iki için birim maliyet \%1,68 oranında daha düşük, ürün üç için ise \%6,32 oranında daha düşük hesaplanmıştır. Genel olarak, FTM-AHP tekniğinin kullanıldığı durumlarda ürünlerin birim maliyeti $\% 19,30-\% 1,68-\% 6,32=\% 11,64$ oranında daha yüksek hesaplanmaktadır.

\section{SONUÇ}

Faaliyet Tabanlı Maliyetleme yönteminde dağıtım anahtarlarının belirlenmesine ihtiyaç duyulmaktadır. Birçok küçük ve orta büyüklükteki işletme, dağıtım anahtarlarının değerlerini etkili bir şekilde belirleyecek altyapıya sahip olmadıklarından problem ile karşılaşılmaktadır. Genel üretim giderlerinin ürünlere yüklenmesine ilişkin ortaya çıkan problemlerin temel nedeni; imalat teknolojilerindeki hızlı gelişmelerin ve değişimlerin, üretim yapılarının değişimini de beraberinde getirmesidir. Çünkü üretim yapılarındaki bu değişimler, ürün maliyetlerinin yapısını büyük ölçüde değiştirmektedir. Dolayısıyla üretimde makine kullanımı artmakta iken çalışan sayısı azaldığından dolayı direkt işçilik giderlerinde önemli azalmalar olmaktadır. Bu noktada; söz konusu giderlerin ürünlere yüklenmesinde kullanılan dağıtım yönteminin ve anahtarının belirlenmesi, makine odaklı üretimin yaygınlaştığı bir ortamda çok daha fazla önemli hale gelmektedir.

İşletmeler dağıtım anahtarlarını (faaliyet sürücüleri) net bir şekilde belirleyemeyebilir. Bu gibi durumlarda, AHP tekniğini kullanmak suretiyle dağıtım katsayıları belirlenebilir ve bu katsayılar yardımıyla maliyet dağıtımı gerçekleştirilebilir. Bu çalışmada, Gaziantep'te gıda sektöründe faaliyet gösteren bir firmanın verilerini kullanmak suretiyle Faaliyet Tabanlı Maliyetleme uygulaması gerçekleştirilmiş ve FTM uygulaması için ihtiyaç duyulan dağıtım anahtarları beş farklı uzmandan elde edilen AHP değerlendirmeleri yardımıyla belirlenmiştir. Uygulanan yöntemin avantajları arasında; sürücüler için ek bilgiye gereksinim duymaması ve farklı görüşlere sahip uzmanların değerlendirmeleri arasında uzlaşı sağlamak suretiyle, tek uzmanın görüşlerinin kullanıldığı duruma göre objektif bir şekilde dağıtım işleminin gerçekleştirilebilmesi sıralanabilir. Bu durum, özellikle veri tutma konusunda yeterli imkâna sahip olmayan küçük ve orta büyüklükteki işletmeler için FTM uygulamasını kolaylaştırmaktadır. AHP tekniğinden farklı olarak, diğer Çok Kriterli Karar Verme Tekniklerinin (ÇKKVT) de kullanılması mümkündür. Ancak AHP tekniği, kolay uygulanabilir olması ve popüler olması nedeniyle tercih edilmiştir. Bununla birlikte bütün ÇKKVT'nin bu çalışmadaki kullanım amacına uygun olarak kullanılması mümkün değildir. Örneğin, TOPSIS, PROMETHEE, ELECTRE, WASPAS gibi teknikler ağırlık atama sürecinde uzmanların görüşlerinden ziyade nesnel verileri kullanmaktadır.

Çalışma sonucunda; işletmenin geleneksel maliyet muhasebesi ile hesaplamış olduğu birim maliyet ile FTMAHP tekniği yardımıyla hesaplanan birim maliyetlerin farklı olduğu tespit edilmiştir. FTM-AHP tekniği ile

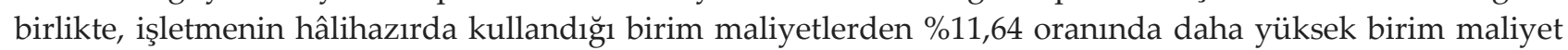
hesaplaması gerçekleştirilmiştir. Bu durum, işletmenin satış hacmine bağlı olarak mali tablolarında önemli değişikliklere neden olabilecektir. Bu nedenle yöneticilerin maliyet sistemlerini gözden geçirmeleri önerilmektedir. Birim maliyetin gerçekçi bir şekilde hesaplanması işletmeye rekabet üstünlüğü sağlayacaktır. Çalışmada incelenen işletmenin endirekt giderleri, direkt giderleri ile karşılaştırıldığında görece düşük düzeyde kalmaktadır. FTM-AHP ile hesaplanacak birim maliyetler ile geleneksel yönteme göre hesaplanan birim maliyetler arasındaki farkın, endirekt giderlerin daha yüksek oranda olduğu işletmeler için daha yüksek çıkacağı tahmin edilmektedir.

Bu çalışmada Faaliyet Tabanlı Maliyetleme kullanılmıştır. İlerleyen çalışmalarda zamana dayalı Faaliyet Tabanlı Maliyetleme yönteminde de AHP ile sürücü belirleme işlemi gerçekleştirilebilir ve erişilen sonuçlar, geleneksel Faaliyet Tabanlı Maliyetleme ile elde edilecek sonuçlar ile karşılaştırılabilir. Ayrıca satış bilgilerine de erişilebilen bir işletmelerde farklı birim maliyet hesaplama durumunun kârlılık üzerindeki etkileri incelenebilir. 


\section{KAYNAKLAR}

Abalı, Y. A., Kutlu, B. S. ve Eren; T. (2012). Çok Ölçütlü Karar Verme Yöntemleri İle Bursiyer Seçimi: Bir Eğitim Kurumunda Uygulama. Atatürk Üniversitesi Iktisadi ve İdari Bilimler Dergisi, 26 (3-4), 259-272.

Akın, O. (2013). Geleneksel Maliyet Muhasebesi Sistemi İle Faaliyet Tabanlı Maliyetleme Sisteminin Karşılaştırılması: Mermer İşletmesi ST (ESTE) hattı örneği. Akademik Araştırmalar ve Çalışmalar Dergisi, 5 (8), 2149.

Angelis, D. I ve Lee, C.Y (1996). Strategic Investment Analysis Using Activity Based Costing Concepts And Analytical Hierarchy Process Techniques. International Journal of ProductionResearc, 34 (5), 1331-1345.

Ar, İ. M., Birdoğan, B. ve Özdemir, F. (2014). Kuruluş Yeri Seçiminde Bulanık AHS-VIKOR Yaklaşımının Kullanımı: Otel Sektöründe Bir Uygulama. International Journal of Economic and Administrative Studies, 7(13), 93-114.

Auzzir, Z., Haigh, R. ve Amaratunga, D. (2018). Impacts of Disaster to SMEs in Malaysia". Procedia Engineering, 212, 1131-1138.

Baykasoğlu, A. ve Kaplanoğlu, V. (2008). Application of Activity-Based Costing to A land Transportation Company: A Case Study. International Journal of ProductionEconomics, 116(2), 308-324.

Bedir, N. ve Eren, T. (2015). AHP-PROMETHEE Yöntemleri Entegrasyonu ile Personel Seçim Problemi: Perakende Sektöründe Bir Uygulama. Social Sciences Research Journal, 4(4), 46-58.

Büyükmirza, H. K., (2011). Maliyet ve Yönetim Muhasebesi Tekdüzen'e Uygun Bir Sistem Yaklaşımı. Ankara: Gazi Kitabevi. 16. Bask1.

Cengiz, E. (2011). Faaliyet Tabanlı Maliyetleme ve Sürece Dayalı Faaliyet Tabanlı Maliyetleme Arasındaki Farklar-Bir Mobilya Üreticisi Firmada Vaka Çalışması. Muhasebe ve Finansman Dergisi, (50), 33-58.

Cooper, R. Ve Kaplan R. S. (1988). Measure Costs Right; Make The Right Decision. Harvard Business Review, 66(5), 96-103.

Cooper, R. Ve Kaplan R. S. (1991). Profit Priorities From Activity-Based Costing. Harvard Business Review, 69(3), 130-135.

Çevik, E ve Gökşen, Y. (2016). Yatırım Projelerinin Değerlendirilmesinde Ahp-Vıkor Entegrasyonu İle Bir Kds Önerisi. Ege Stratejik Araştırmalar Dergisi, 7(2), 219-235.

Da Rocha, L. S, SLoane, E. B. ve Bassanı, José W.M. (2005). Optimal Medical Equipment Maintenance Service Proposal Decision Support SystemCombining Activity Based Costing and the Analytic Hiyerarchy Process (AHP). 27th Annual Conference on Engineering in Medicine and Biology, 7103:7106.

Dağsuyu, C., Dere, E. B. ve Kokangül, A. (2016). AHP-WRA Bütünleşik Yöntemi Kullanılarak Mobilya Sektöründe Müşteri Şikayetlerinin Değerlendirilmesi. Çukurova Üniversitesi Mühendislik-Mimarlık Fakültesi Dergisi, 31(2), 129-138.

Dijkstra, T. K (2013). On The Extraction Of Weights From Pairwise Comparison Matrices". Central European Journal of Operations Research,21(1), 103-123.

Durmuş M. ve Tayyar N. (2017). AHP ve TOPSIS ile Farklı Kriter Ağırlıklandırma Yöntemlerinin Kullanılması ve Karar Verici Görüşleriyle Karşılaştırılması. Eskişehir Osmangazi Üniversitesi İ̈BF Dergisi, C. 12, S. 3, 65 $-80$

Eraslan, E ve Algün, O. (2005). İdeal Performans Değerlendirme Formu Tasarımında Analitik Hiyerarşi Yöntemi Yaklaşımı" Gazi Üniversitesi Mühendislik-Mimarlık Fakültesi Dergisi, 20(1), 95-106.

Esmeray, M. ve Güngör Tanç, Ş. (2009). Çevresel Maliyetlerin Mamullere Yüklenmesinde Kullanılan Dağıtım Anahtarlarının Seçiminde Analitik Hiyerarşi Yöntemi ve Bir Uygulama. Süleyman Demirel Üniversitesi İktisadi ve İdari Bilimler Fakültesi Dergisi, 14(2), 241-260.

Ganorkar, A. B.,Lakhe, R. R. ve Agrawal, K. N. (2018). Implementation of TDABC in SME: A casestudy. Journal of Corporate Accounting \& Finance, 29(2), 87-113. 
M. Özçalıcı - A. Kaya 11/4 (2019) 3035-3050

Horngren, C. T., Datar, S. ve Rajan, M.(2015). Cost Accounting: A Managerial Emphasis. Pearson Education. 15.th Global Edition. Boston.

Kabinlapat, P. Ve Sutthachai, S. (2017). An Application of Activity-Based Costing in the Chicken Processing Industry: A Case of Joint Products. International Food and Agribusiness Management Revi,. 20(1), 85-97.

Karaoğlan S. ve Şahin, S. (2018). BİST XKMYA İşletmelerinin Finansal Performanslarının Çok Kriterli Karar Verme Yöntemleri İle Ölçümü ve Yöntemlerin Karşılaştırılması. Ege Akademik Bakış Dergisi, 18(1), 63-80.

Kazançoğlu, Y. ve Ada, E. (2010). Perakende Sektöründe Tedarikçi Seçiminin Bulanık AHP ile Gerçekleştirilmesi. Savunma Bilimleri Dergisi, 9(1), 29-52.

Kuruüzüm, A. ve Atsan, N. (2001). Analitik Hiyerarşi Yöntemi ve İşletmecilik Alanındaki Uygulamaları. Akdeniz İ̈BF Dergisi, 1, 83-105.

Lin, W.C. (2012). Financial Performance And Customer Service: An Examination Using Activity-Based Costing Of 38 International Airlines. Journal of Air Transport Management, 19, 13-15.

Ömürbek, N., Tunca, M. Z., Özcan, A., Yıldız, E. ve Karataş, T. (2016). Ahp Topsis Yönteminin Tipta Uzmanlık Alan Seçiminde Kullanım. Akdeniz Üniversitesi İktisadi ve İdari Bilimler Fakültesi Dergisi, (33), 201-219.

Ömürbek, N., Tunca, M. Z. (2013). Analitik Hiyerarşi Süreci ve Analitik Ağ Süreci Yöntemlerinde Grup Kararı Verilmesi Aşamasına İlişkin Bir Örnek Uygulama. Süleyman Demirel Üniversitesi İiBF Dergisi, 18(3), 4770.

Özbek, A. (2017). Çok Kriterli Karar Verme Yöntemleri ve Excel İle Problem Çözümü Kavram- Teori- Uygulama, Seçkin Yayınları, Ankara.

Özçalıcı, M (2017). MATLAB ile Çok Kriterli Karar Verme Teknikleri. Nobel Yayınevi, Ankara.

Partovi, F. Y. (1991). An Analytic Hierarchy Approach To Activity-Based Costing. International Journal of Production Economics, 22, 151-161.

Ríos-manríquez, M., Colomina, C. I. M. Ve Pastor, M. L. R.V. (2014). Is the Activity Based Costing System a Viable Instrument for Small And Medium Enterprises? Thecase of Mexico. Estudiosgerenciales, 30(132), 220-232.

Saaty, T. L. Ve Vargas, L. G. (2012). Models, Methods, Concepts \& Applications of the Analytic Hierarchy Process. New York: Springer Science+Business Media.

Shashikumar, G., Sarkar, B. ve Sanyal, S.K. (2017). Evaluation of Facilities Layout Alternatives by Integrating Concepts of ABC \& AHP". International Journal of Engineering Science Invention, 6(7), 20-25.

Slack, N.,Brandon-jones, A. ve Johnston, R. (2013). Operations Management, Harlow: Pearson Education Limited, Seventh Edition.

Taha, H. (2011). Operations Research: An Introduction, New Jersey: Pearson Higher Education.Ninth Edition.

Tayyar, N. ve Arslan, P. (2013). Hazır Giyim Sektöründe En İyi Fason İşletme Seçimi İçin AHP ve VİKOR. Celal Bayar Üniversitesi Sosyal Bilimler Dergisi, 11(1), 340-358.

Tüminçin, F. (2016). Analitik Hiyerarşik Proses (AHP) İle Bir Karar Destek Sistemi Oluşturulması: Bir Üretim İşletmesinde Uygulama, (Yüksek Lisans Tezi, Bartın Üniversitesi, Sosyal Bilimler Enstitüsü, Bartın).

Tsai, W.H. ve Kuo, L. (2004). Operating Costs And Capacity In The Airline Industry. Journal of Air Transport Management, 10, 271-277.

Unutkan, Ö. (2010). Faaliyet Tabanlı Maliyet Sistemi Ve Bir Uygulama. Mali Çözüm Dergisi, (97). 87-105.

Yarıkkaya, E.,Özekinci, S., Sargan, A., Erdoğan Durmuş, Ş. Ve Yıldız, F.R. (2017). “A Comparative Study of Activity-Based Costing vs. Current Pricing System for Pathology Examinations at Okmeydani Training and Research Hospital Turkey. TurkishJournal of Pathology, 33(1), 017-024.

Yıldırım Söylemez, E. ve Koç, Y. D. (2017). Çok Kriterli Karar Verme Yöntemleri İle Optimal Portföy Seçimi: Borsa İstanbul Örneği. Uşak Üniversitesi Sosyal Bilimler Dergisi, 10, 117-133. 